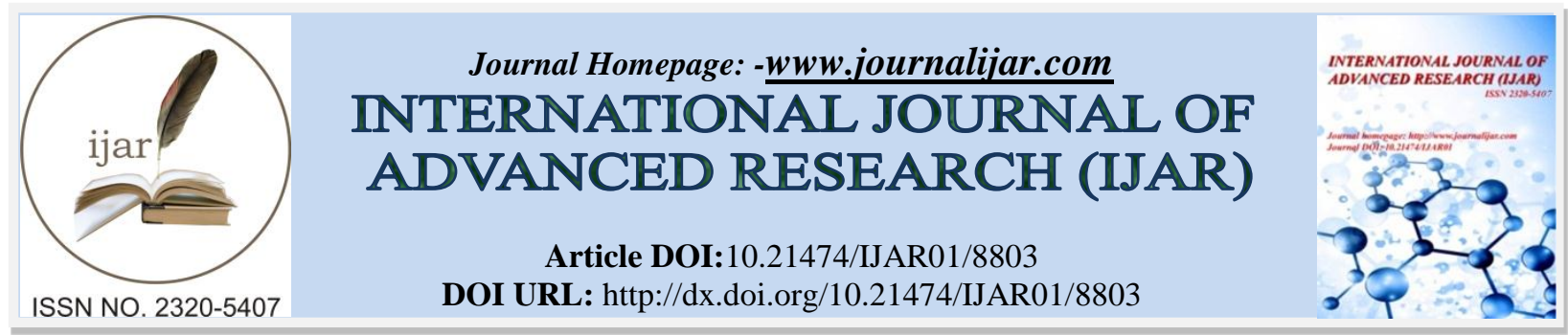

RESEARCH ARTICLE

\title{
RECONSTRUCTION OF SECURITY LAW ON FINANCING AGREEMENTS IN THE CONTEXT OF JUSTICE-BASED FIDUCIARY REGISTRATION.
}

OK Isnainul, Gunarto and Darwinsyah Minn.

Doctorate Student of PDIH Faculty of Law Unissula.

\section{Manuscript Info}

\section{Manuscript History}

Received: 04 February 2019

Final Accepted: 06 March 2019

Published: April 2019

Key words:-

Reconstruction, Agreement, Financing, Fiduciary.

\begin{abstract}
Along with the increasing economic development and increasing and increasing needs, the costs needed will be even greater, both for life needs and for businesses where the costs needed are mostly obtained from lending and borrowing activities. In these lending and borrowing activities, there are legal products used by the community in the form of guaranteeing goods to obtain financing. This is where fiduciary security is present to meet legal needs in guaranteeing lending and borrowing activities. The purpose of this study is to find out the application of fiduciary guarantee law No. 42 of 1999, The main objective of this study is to design an ideal legal reconstruction of the Fiduciary Guarantee Law No. 42 of 1999 so that law enforcement and legal compliance are being the ideal of this Act can be realized ideally and optimally. This study uses normative legal research which includes legal principles, legal systematics, legal synchronization, comparative law and legal history.There are 2 important findings in this study, First, there is uncertainty in sanctions in the Fiduciary Guarantee Law, so this makes the Law not have the power in the application of the law. Secondly, there is inconsistency and disharmony in the Fiduciary Guarantee Law and the Minister of Finance Regulation which are the implementing regulations, so that law enforcement from this law is not optimal as Normative Law and Fiduciary Law does not have forced efforts in terms of law enforcement for necessity in conducting fiduciary registration. Due to the weaknesses of the Fiduciary Guarantee Law No. 42 of 1999, researchers see that it is very necessary for an ideal Reconstruction of the Fiduciary Guarantee Law so that law enforcement and Legal Compliance can be realized with an ideal, Optimal and fulfilling sense of Justice.
\end{abstract}

Copy Right, IJAR, 2019,. All rights reserved.

\section{Introduction:-}

Fiduciary is a term that has long been known in Indonesian. The law specifically regulating this matter, namely Law No.42 of 1999, also uses the term "Fiduciary". Thus, the term fiduciary has become and is an official term in our legal world. However, sometimes in Indonesian for fiduciary this is also referred to as the term "Trusting Ownership of Property" . In the terms of the Dutch, it is often referred to as the full term "Fiduciare Eigendom Overdracht", whereas in full English it is often referred to as "Fiduciare Transfer of Ownership" .

Corresponding Author:-OK Isnainul.

Address:-Doctorate Student of PDIH Faculty of Law Unissula. 
Since the birth of fiduciary guarantees this is very thick with engineering (in the positive sense). Because in the old Dutch legal system it was also in Indonesia, for the guarantee of movable ire only known as pawn (Pand). While for immovable goods known as Hypothek. However, there is a need in practice to guarantee movable property, but without physical delivery of goods. For this purpose, it cannot be used in a mortgage guarantee institution (which requires the surrender of objects from the pawnshop) and also cannot be used for hypotension (which is only intended for immovable property). Therefore, find a way to be able to guarantee movable goods without any physical delivery of the goods. Finally an engineering emerged that fulfilled the interests of such practices, by providing fiduciary guarantees, which were finally accepted in practice and recognized by jurisprudence in Indonesia.

The legal engineering is carried out through its global form called the "Constitutum Possesorium" (surrender ownership of objects without giving up physical objects at all). As is well known that the basis of fiduciary guarantees is an agreement, precisely a fiduciary agreement, while this fiduciary engagement has the following characteristics:

1. Between the fiduciary giver and the fiduciary recipient there is an engagement relationship, which issues the right for the creditor to request the surrender of collateral from the debtor in a constitutum possession.

2. The engagement was an engagement to provide something, because the sight of debtors submit a Possesorium titutum Cons goods to the creditor.

3. Engagement in the framework of fiduciary giving is an agreement that is in the nature of an assessment, which is an engagement that follows the birth agreement (the main agreement is in the form of debt receivables) .

4. Fiduciary engagement is classified into an agreement with a null condition, because if the debt is repaid, then the collateral rights are fiduciary deleted.

5. Fiduciary engagement is classified into an agreement originating from an agreement, namely a fiduciary agreement.

6. The fiduciary agreement is an agreement that is not specifically mentioned in the Civil Code, therefore this agreement is classified as an unnamed agreement (Onbenoemde Overeenkomst).

7. However, of course the fiduciary agreement is still subject to the provisions of the general section of the engagement contained in the Civil Code [1].

Before they are published in the form of a special law on the fiduciary, in Indonesi a similarly to what happened in the Netherlands, that this fiduciary institution initially evolved through jurisprudence, as we have mentioned above. Indeed, since the days of the Dutch East Indies, in Indonesia it was felt the need for practice towards an institution such as fiduciary, because there were shortcomings found in the KUH Perdata or other Law pawn and hypotension institutions.

The current fiduciary guarantee agreement is very often used, especially in the field of finance business. Where is the finance company in running its business.

Guarantee as a legal institution gave birth to the principles of law set forth in the civil law that have to dud $u$ kan important in economic law. The guarantee institution in the form of a mortgage stipulated in Book II of the Civil Code is felt not to meet the needs of the community, especially small entrepreneurs, given the provisions contained in article 1152 of the Civil Code, which requires that tangible movable objects provided as collateral in the form of pawns must move and is in the possession of the creditor (Inbezitstelling), while the goods referred to as objects of guarantee are still needed by those who are indebted in carrying out their business.

To deal with the provisions of article 1152 paragraph 2 of the Civil Code and fulfill the community's need for guarantee institutions, Law No. 42 of 1999 concerning Fiduciary Assurance, which states in article 1 that the purpose of fiduciary is the transfer of ownership rights to an object based on trust with the provisions for objects whose ownership rights are transferred remain in the possession of the owner of the object. The rules for fiduciary guarantees by Sri Rezeki Hartono are included in the economic law because Fiduciary guarantees according to him are commonly used and used in the practice of business or economics, because there are several reasons, including practical and safe, such guarantees are collateral for debts debt, which gives the main position to fiduciary holders in this case as creditors to other creditors as regulated in Law No. 42 of 1999 concerning Fiduciary Guarantees [2].

Fiduciary guarantees when viewed from the legal aspect provide preferences (repayment rights) from other creditors (concurrent) as follows: 
1. The fiduciary has rights that take precedence over other creditors.

2. The fiduciary holder has the right to take precedence over taking the repayment of the receivables for the results of the execution of objects which are objects of fiduciary collateral.

3. The fiduciary has rights that are not prioritized due to bankruptcy and or liquidation [3].

Fiduciary guarantees with the principle of "Constitutum Possesorium" (surrender of ownership of objects without giving up physical objects at all), are currently suspected to be still based on jurisprudential practices and have not guaranteed legal certainty (certainty legal). In an era of democracy, the issue of legal certainty is one of the basic values (core value) within the framework of the rule of law, which include the principles that States have pioneered the observance of the law, the independent judicial power (Independence of Judiciary), access to justice (access to justice) must be opened as widely as possible, especially for those who are victims of "maladministration" , the law must be enforced fairly and equally (just, equal) accompanied by legal certainty [4].

\section{Main Problem}

Based on what has been described in the background, several problems can be formulated as follows:

1. Why is the Law on Fiduciary Guarantees No. 42 of 1999 specifically regarding Fiduciary registration obligations not complied with by Financing Companies?

2. How is Law Enforcement of the Fiduciary Guarantee agreement not registered with the Regional Office of the Ministry of Law and Human Rights in North Sumatra Province / Ministry of Law and Human Rights ?

3. What is the Ideal Legal Reconstruction to guarantee the proper functioning of registration for a fair Fiduciary Guarantee?

\section{Research Purposes}

In principle, the aim of the research in a scientific paper is to point to the problems that have been formulated, this is nothing but to answer all these problems, because the objectives of this paper are:

1. To study and find out that business people, especially finance companies, do not comply with Fiduciary Guarantee Law No. 42 of 1999 specifically regarding Fiduciary registration.

2. To review and find out Law Enforcement that will be carried out by Law Offices and Ham Offices, against Fiduciaries who are not Registered.

3. To review and find ideal legal reconstruction so that justice-based Fiduciary registration can be carried out.

\section{Research Benefit}

The benefits of this study are as follows:

1. Theoretically, it is expected that this research is an enhancer of knowledge in the repertoire and development of legal science especially in relation to the development of business law today.

2. In practical terms, it is expected that the results of this study can be used as material for thought in solving all the problems that occur and those faced by stakeholders in terms of financing with fiduciary guarantees.

\section{Grand Research Theory}

- Justice Theory and Legal Certainty of Gustav Radbruch.

Law scientist and also a German bureaucrat and politician from the Relativism school Gustav Radbruch (1878-1949) was very influential in the world of law.

According to Gustav Radbruch justice, legal certainty, and expediency (Gustav Radbruch: Gerechtigkeit, Rechtssicherheit, Zweckmäßigkeit ) are three terminologies that are often sung in lecture halls and judicial rooms, but not necessarily understood the nature or agreed meaning. Justice and legal certainty, for example. At a glance the two terms are opposite, but it may not be the same. The word justice can be an analog term, so it presents the terms procedural justice, legalist justice, commutative justice, distributive justice, vindicative justice, creative justice, substantive justice, and so on. Procedural justice, as termed by Nonet and Selznick to refer to one of the indicators of an autonomous legal type, for example, it turns out that after being examined it leads to legal certainty for the sake of the rule of law. So, in this context justice and legal certainty are not at odds, but rather side by side [5].

Justice and Certainty are two axiological values in the law. The philosophy of law discourse often questions both of these values as if they are antinomies, so the philosophy of law is interpreted as the search for justice with certainty or certainty that is just [6]. 
Gustav Radbruch's view generally means that legal certainty does not always have to be given priority in fulfilling every positive legal system, as if legal certainty must exist first, then justice and expediency. Gustav Radbruch then corrected his theory that the three legal objectives are equal [7].

Gustav Radbruch, the originator of three basic legal values from Germany, once said that a good law is when the law contains the value of justice, legal certainty and usability. That is, even though all three are basic legal values, each value has different demands from each other, so that all three have the potential to contradict each other and cause tension between the three values (Spannungsverhältnis) [8].

Therefore, law as the bearer of the value of justice, asserted Radbruch, could be a measure for the fairness of the rule of law. Therefore, the value of justice is also the basis of the law as law. Thus, justice has a normative and constitutive nature for the law. In this case, justice is a legal moral basis and a benchmark for a positive legal system. Therefore, to justice, positive law stems. While constitutive, because justice must be an absolute element of the law. That is, law without justice is a rule that does not deserve to be a law.

Legal Justice Theory.

Justice is the glue of civilized social life. Laws are created so that each individual member of the public and state officials to do something ti $\mathrm{n}$ dakan necessary to maintain social cohesion and achieve the goal of living together or otherwise to refrain from any act that may damage the order of justice.

Justice is indeed an abstract conception. However, the concept of justice contains the meaning of protection of rights, equality of degree and position before the law, as well as the principle of proportionality between individual interests and social interests. The abstract nature of justice is because justice cannot always be born of rationality, but it is also determined by a social atmosphere that is influenced by other values and norms in society. Therefore justice also has a dynamic nature which sometimes cannot be contained in positive law [9].

Fair in essence means putting things in place and giving to anyone what is their right, which is based on a principle that all people are equal before the law ( equality before the law ).

\section{Legal Certainty Theory.}

Legal certainty as one of the objectives of the law can be said as part of efforts to realize justice. The real form of legal certainty is the implementation or law enforcement of an action regardless of who does it. With the existence of legal certainty, everyone can estimate what will be experienced if they do certain legal actions. Certainty is needed to realize the principle of equality before the law without discrimination.[10] Certainty is a feature that cannot be separated from the law, especially for written legal norms. Law without the value of certainty will lose meaning because it can no longer be used as a guideline for everyone. Certainty itself is called as one of the objectives of the law. [11]

The word "certainty" is closely related to the principle of truth, that is, something that can be strictly legally formal. Through deductive logic, the rules of positive law are placed as a major premise, while concrete events become minor premises. Through a closed logic system, conclusions can be obtained immediately. The conclusion must be something that can be predicted, so that everyone must stick to it. With this handle the community becomes orderly. Therefore, certainty will direct society to order. [12]

Legal certainty will guarantee that someone conducts behavior in accordance with applicable legal provisions. Conversely, without legal certainty, a person does not have standard provisions in carrying out behavior.

\section{Midle Research Theory .}

\section{Legal System Theory}

In accordance with the research title and the things that will be discussed in this study, in essence, is about the Legal Reconstruction of Guarantees. Reconstruction is a renewal, a question that arises, why should it be updated? Because it feels there is a discrepancy, as we know that the Legal Purpose at its core is legal certainty, benefit and justice. The occurrence of reconstruction because the purpose of law is not yet fully achieved. Therefore, there is what is called legal renewal or reconstruction so that legal objectives can be achieved.

according to Lawrence Friedman. Friedman divides the legal system into three (3) components, namely: [13] 
1. The substance rule of the law, inside it covers all written and unwritten rules, both material law or formal law.

2. Structure of the law, covers legal institutions, legal apparatus and law enforcement system. Legal structures are closely related to the justice system carried out by law enforcement officials, in the criminal justice system, the application of law enforcement is carried out by investigators, prosecutors, judges and advocates.

3. Legal culture, is emphasis from the cultural side general, habits, opinions, ways of acting and thinking, which direct social power in society.

The three components of the legal system according to Lawrence M Friedman above are the soul or spirit that moves the law as a social system that has special character and technique in its study.

Applied Theory.

In Applied Theory in this writing, it is used namely,

Theory of Compliance with Law.

Compliance of law in society is one part of legal culture, in legal culture can be seen from the tradition of everyday community behavior that is in line and reflects the will of legal signs that apply to all legal subjects, the emergence of legal compliance begins with public legal awareness. Legal awareness can grow because of the fear of sanctions imposed.

According to Robert Biersted in his book The Social Order , the process of one's compliance with the law may occur due to several factors, namely:

1. Indoctrination (intentional obedience planting), which is a legal regulation that becomes a doctrine that is planted intentionally to the community. This is done so that the application of the law is evenly distributed to all levels of society, so that the desired legal compliance can be realized.

2. Habituation (Habituation Behavior), that a person comply with legal regulations because the routines they do, like someone wearing a helmet when driving a motorcycle.

3. Utility (Utilization of the obeyed method), that is, someone obeys the law because it can substantially utilize the regulation.

4. Group Identification (Identifying in certain groups), ie someone will obey the law when seeing or referring to a group that has implemented the law. [14]

However, it should also be noted that even though a norm has been socialized in such a way and has been institutionalized, it is not necessarily the norm that has truly been absorbed (internalized) in each member of the community.

The problem above identifies that a legal product that is made is solely for the common good, in this case the process of socializing legal regulations plays an important role so that its implementation can run well. [15]In particular at this time, the legal compliance of fiduciary collaterals is not yet fully aware of the applicable law, so that there are still many of them who have not yet complied with the law to carry out fiduciary registration in accordance with what has been mandated by law. fiduciary guarantee law that has been applied as a positive law governing fiduciary as a whole in theory and practice. So from this, the author is interested in examining the level of compliance of financing business players, especially financing motor vehicles in the city and surrounding areas in carrying out fiduciary registration of fiduciary guarantee agreements that have been made against debtors who have been regulated in fiduciary insurance law (Law No. 42 of 1999).

\section{Theory of Enforcement of Law}

The definition of law enforcement can also be interpreted as administering law by law enforcement officers and by anyone who has an interest in accordance with their respective authorities according to the applicable legal rules. According to Soerjono Soekanto, law enforcement is an activity that harmonizes the relationship of the values described in the rules of solid and action as the series of translation of the final stages. To create, maintain and maintain the peace of life.[16] .

In other words, law enforcement is the implementation of regulations. Thus, law enforcement is a system that involves harmonizing values with real human rules and behaviors. These rules then become guidelines or 
benchmarks for behavior or actions that are deemed appropriate or appropriate. The behavior or attitude of action is aimed at creating, maintaining and maintaining peace.

In terms of law enforcement factors, it makes the law rule truly function, according to Soerjono Soekanto, the factors are:

Own legal factors or the rules themselves.

Can be seen from the existence of laws and regulations, which are made by the government hoping for a positive impact that will be obtained from law enforcement. Run according to the laws and regulations, so as to achieve effective goals. In the law itself there are still problems that can hinder law enforcement, namely:

1. Not followed by the principles of the enactment of the law.

2. The absence of implementing regulations is needed to implement the law.

3. The ambiguity of the meaning of the word in the law which results in confusion in the interpretation and application.

4. Factors in law enforcement, namely those who form and enforce the law, the term law enforcement includes those who directly or indirectly engage in law enforcement, such as in the field of justice, police, law and social affairs.

5. Factor facilities or facilities that support law enforcement.

6. Certainty of handling a case always depends on the input of resources given in prevention programs. It is impossible peneg a legal right will go smoothly without any particular means or facilities providing support dala $\mathrm{m}$ implementation.

7. Community factors, namely environmental factors where the law is applied or enforced.

8. Law enforcement comes from the community and aims to achieve peace within the community itself. Directly the community can influence law enforcement.

9. Cultural Factor (Culture)

10. Namely as a result of work, creativity and a sense that is based on human intention in life.

Fiduciary Guarantee on Financing Agreements According to Law No. 42 of 1999 concerning Fiduciary Guarantees.

Guarantee as a legal institution gave birth to the principles of law set forth in the civil law that have to stand is important in economic law. The guarantee institution in the form of a mortgage stipulated in Book II of the Civil Code is felt not to meet the needs of the community, especially small entrepreneurs, given the provisions contained in article 1152 of the Civil Code, which requires that tangible movable objects provided as collateral in the form of pawns must move and is in the possession of the creditor (Inbezitstelling), while the goods as objects of security guarantee are needed by those who are indebted in carrying out their business.

To mengatasai provisions of paragraph 2 of Article 1152 of the Civil Code and meet community needs a guarantee Bodies, born Law U ndang No. 42 of 1999 on Fiduciary, which states in Article 1 that the intent of the fiduciary transfer of ownership of an object on the basis of trust with the provisions for objects whose ownership rights are transferred remain in the possession of the owner of the object. The rules for fiduciary guarantees by Sri Rezeki Hartono are included in the economic law because Fiduciary guarantees according to him are commonly used and used in the practice of business or economics, because there are several reasons, including practical and safe, such guarantees are collateral for debt repayment, which gives the main position to fiduciary holders in this case as creditors to other creditors as regulated in Law No. 42 of 1999 concerning Fiduciary Guarantees. [17]

Fiduciary guarantees with the principle of "Constitutum Possesorium" (surrender of ownership of objects without giving up physical objects at all), are currently suspected to be still based on jurisprudential practices and have not guaranteed legal certainty (certainty legal) . In an era of democracy, the issue of legal certainty is one of the basic values (core value) within the framework of the rule of law, which include the principles that States have pioneered the observance of the law, the independent judicial power (Independence of Judiciary), access to justice (access to justice) must be opened as widely as possible, especially for those who are victims of "maladministration" , the law must be enforced fairly and equally (just, equal) accompanied by legal certainty. [18]

Assessing the renewal siste $\mathrm{m}$ national law are major problems in the national legal system, namely the ius constitutum (the problem of "Law Enforcement) and Ius constituendum (the problem of" Law reform / development).[19] Likewise with fiduciary guarantees, as one of the national laws in practice raises various legal problems including the absence of legal certainty and legal protection. The inconsistency of the substance of a 
fiduciary guarantee institution, the structure of a fiduciary institution that is not in favor of SMEs (Small and Medium Enterprises), the unfairness of the Judge in deciding cases of fiduciary guarantees makes this law ineffective.

From the theoretical / conceptual point of view, the renewal of the National fiduciary guarantee legal system is a unit of the legal sub-system of Fiduciary Security into the legal substance of Fiduciary Guarantee and legal culture of fiduciary guarantees. The National Legal System that will be built requires a foundation of values / ideas as guidelines that are in accordance with the views of life and ideology of the Indonesian Nation so that the legal knowledge can apply nationally. Its law and enforcement experienced a close and intensive exchange with the pocitical and economic environment.

\section{Fiduciary Assurance Is Not a Stand-alone Agreement}

Before the issuance of Law No. 42 of 1999, legal experts still disagreed regarding the nature of the fiduciary agreement. The first opinion says that the fiduciary guarantee agreement is independent (Zelfstanding). The results of the study indicate that the fiduciary guarantee agreement is an agreement that was born and inseparable from the Bank's credit agreement or debt agreement. This means that the fiduciary guarantee agreement cannot exist without being preceded by another agreement which is referred to as the principal agreement.

In the Bank's practice, the relationship between the nature of the fiduciary guarantee agreement and the loan agreement can be seen from the contents of the fiduciary guarantee agreement both before and after the birth of fiduciary guarantee law No. 42 of 1999. Before the issuance of the fiduciary guarantee law, the fiduciary guarantee agreement was carried out in the form of a deed under the hands and deeds in the form of authentic (notary deed). The results of this study still show a similarity with the 1989 fiduciary research report, which said that in the practice of binding fiduciary guarantees on movable objects can be done by Notary deed $(58.6 \%)$ and underhanded deeds $(41.4 \%)$. [19]

The description shows that there is no certainty about the form of a fiduciary guarantee agreement. This is because there are no provisions governing it, but it has become a habit among banks that a fiduciary guarantee agreement must be made in writing.

Different from the situation after the issuance of the fiduciary guarantee law, the form of a fiduciary guarantee agreement was explicitly determined so that it was made with a Notary deed. [20]One of the reasons for establishing the Law stipulates that the Notary deed is an authentic deed, so that it has the power of perfect proof, the same reason was also stated by the Notaries. [21] Confirmation of the form of a fiduciary guarantee agreement with a Notary deed by the Fiduciary guarantee law must be interpreted as a compelling legal norm (Imperative is not facultative), meaning that if the fiduciary guarantee agreement is carried out in the form of notary deed, legally the fiduciary guarantee agreement never existed. This will become clearer if it is associated with the process of fiduciary collateral when registering at the office fiduciary registration in this case the Ministry of Law and Human Rights. Applicants for fiduciary guarantee registration must be accompanied by a copy of the notary deed concerning the imposition of fiduciary guarantees. [22] The next juridical consequence is, is a very important series and determines the birth of fiduciary guarantees. [23]

With the results of this study it can be concluded that, doubts about the nature of the fiduciary guarantee agreement are not in question anymore because the empirical juridical facts have supported the opinion that fiduciary guarantee agreements are agreements that are not independent agreements.

\section{Fiduciary Security Contract Registration}

Registration have juridical significance as a circuit that is not separate from the process of a fiduciary agreement. In addition, registration of fiduciary guarantees is a manifestation of the principle of publicity and legal certainty.

Although registration of fiduciary guarantees is so important, in the practice of credit within the Bank there are still fiduciary collateral agreements that are not registered. [24] Likewise what happened to the fiduciary guarantee agreement within the financial institution. The legal effect of the fiduciary guarantee agreement that is not registered is that it does not give birth to material agreements for fiduciary guarantees, so material characteristics such as droit de suite and preference rights are not attached to fiduciary guarantors. In practice there are still doubts regarding the 
registration of fiduciary guarantees. The doubt is the lack of clarity in the Fiduciary Guarantee Law to determine what is registered.

To provide legal certainty, article 11 of the Fiduciary guarantee law requires objects loaded with fiduciary guarantees to be registered with the fiduciary registration office located throughout Indonesia. This obligation even applies even though the material burdened with fiduciary guarantees is outside the territory of the unitary state of the Republic of Indonesia. The registration of objects loaded with fiduciary guarantees is carried out at the place of the fiduciary provider and their registration includes objects both inside and outside the territory of the Republic of Indonesia. To fulfill the principle of publicity, it is also a guarantee of certainty for other creditors regarding objects that have been burdened with fiduciary guarantees.

Thus the registration of fiduciary guarantees in the fiduciary register is constitutive action which gives birth to fiduciary guarantees. We can see further confirmation in the provisions of article 28 of the fiduciary guarantee law which states that if the same object becomes the object of guarantee fiduciary more than 1 (one) fiduciary guarantee agreement, then the creditor who first registers is a fiduciary recipient. This is important to note by creditors who are parties to the fiduciary guarantee agreement, because only the fiduciary recipient, the power of attorney or his representative may register fiduciary guarantees. Further provisions regarding the procedure for registration of fiduciary guarantees and registration fees will be governed by government regulations. As evidence for the creditor that he is the holder of fiduciary collateral is a fiduciary guarantee certificate issued by the fiduciary registration office on the same date as the date of receipt of the application for registration. This fiduciary guarantee certificate is actually a copy of a ri fiduciary list book that contains the same things as the data and information that existed when the registration statement. Provisions regarding the existence of fiduciary collateral registration obligations can be said to be an important breakthrough, given that in general the object of fiduciary collateral is an unregistered movable object so that it is difficult to know who the owner is.

This breakthrough will be more meaningful if we associate it with the provisions of article 1977 of the Civil Code which states that whoever controls a moving object is considered the owner (bezit als volkome title) . [25]That is why FEO and Cessi are said to be guarantees that do not provide protection for the creditor holders, namely because there is no registration such as a fiduciary guarantee institution. Thus fiduciary guarantees fulfill the principle of publicity as one of the very important principles in the material guarantee law.

\section{Fiduciary Certificate and Proof of Strength.}

Because the fiduciary certificate is issued by a legitimate agency and authority in this case the fiduciary registration office, then the certificate has very strong evidentiary power as an authentic certificate and only the fiduciary registration office is the only one authorized to issue the fiduciary guarantee certificate, because also, if there is a proof of fiduciary certificate and the certificate is valid. So if there is other evidence in any form must be rejected. The parties are not enough, for example, only prove the existence of a fiduciary by only showing a fiduciary deed made by a Notary. Because, according to Article 14 paragraph 3 of the Fiduciary Guarantee Law No. 42 of 1999, then with a fiduciary guarantee deed, a fiduciary institution is deemed not yet born,the birth of the fiduciary is when registered at the fiduciary registration office. [26]Based on the statement of article 14 paragraph 3 of the Fiduciary Guarantee Act, it can be concluded here that the registration of a fiduciary guarantee deed is an absolute one and is a necessity so that a fiduciary guarantee deed has a permanent and legal legal power as a guarantee deed fiduciary.

\section{Enforcement Of Law In Reconstruction Of Legal Guarantee Systems In Fiduciary Registration Context Legal Enforcement carried out by the Fiduciary Registration Office}

The background of the birth of a fiduciary institution is because of the need in practice. These needs are based on the facts that according to our legal system if the object of collateral is a moving object, then the guarantee is bound in the form of a mortgage, where the object of the guarantee must be submitted to the party receiving the mortgage (creditor). Conversely, if the object of collateral is a immovable object, then the guarantee must be hypothetical (there are now mortgage rights), where the object of the guarantee is not handed over to the creditor, but remains within the authority of the debtor.

However, there are cases where the object of collateral debt is still classified as a movable item, but the debtor is reluctant to give up power over the item to the creditor, while the creditor does not have an interest or even hassle if the item is handed over to him. Therefore, there is a need for a form of debt security whose object is still classified as a movable object but without giving power to the object to the creditor. 
Finally comes the new guarantee form where the object is moving objects, but the power over the object does not switch from the debtor to the creditor. This is called Fiduciary guarantee.

Therefore, with the rapid growth of the automotive industry with the sale of new motorized vehicles which are quite high, $70 \%$ with credit facilities, therefore Therefore, to protect the financial industry, especially multifinance companies, the Government and Parliament created a new legal institution by giving birth to a legal code called Fiduciary guarantee which was marked by the birth of Fiduciary Guarantee Law No. 42 of 1999 which aimed to regulate and provide legal certainty for parties in material guarantees by pledging objects that are not land that cannot be accommodated by hypotheses, mortgages or liens. Fiduciary guarantee is different from fiduciary before the birth of the Fiduciary Guarantee Law, because fiduciary guarantees must be made in the form of authentic certificates (Notaril) and given new rights in the form of executorial titles, where the execution parate can be carried out immediately by the creditor without going through a permanent court decision without going through the court bailiff.

For this reason, fiduciary guarantees can be valid and have a permanent legal force, the fiduciary guarantee deed must be registered and issued by a fiduciary guarantee certificate with the rationale "For the sake of justice based on the One-ty", so that the fiduciary guarantee can be carried out immediately by parate execution.

Finance companies generally only proceed with making fiduciary deeds and registering them for the issuance of fiduciary guarantee certificates if it is deemed necessary, ie if the debtor has manifested defaults by not paying or delinquent payments for installments of motorized vehicles. Even if the withdrawals made by multifinance companies do not get into trouble or the debtors are willing to give up their motorized vehicles voluntarily, multifinance companies will not make fiduciary deeds and register them.

In general, to finance the purchase of a motorcycle whose credit is below Rp. 20,000,000 (twenty million rupiahs), the finance company only makes a power of attorney to charge the fiduciary under the hand with a stamp of Rp. 6,000 (six thousand rupiah) without any ratification (legalization) or registration (warmerking) Notary. Fiduciary deed will only be made and registered if the finance company has difficulties or resistance from the debtor when withdrawing collateral vehicles from defaulting debtors. However, so that fiduciary guarantees can provide legal certainty and protection for those concerned, fiduciary guarantees need to be registered at the fiduciary collateral registration office.

The rapid growth of the automotive industry in Indonesia, which amounts to $11 \%$ / year from domestic gross income. [27] Where in 2015 for motorcycle sales reached 7,771,018 motorcycles. [28] whereas in 2015 car sales had just reached 1,229,904 units, of which $70 \%$ were purchased on credit. This makes the financing market for motorized vehicles in Indonesia very large. from the data it can be seen that the potential of Non-Tax State Revenues (PNBP) lost from fiduciary guarantees is very large if the fiduciary guarantee is not registered.

The Financial Services Authority (OJK) revealed the results of the examination of the Financial and Development Supervisory Board (BPKP) and the Corruption Eradication Commission (KPK) to find potential state losses carried out by motor vehicle financing companies. The state, because many fiduciary registrations have not been carried out by finance companies. The findings of the BPKP and KPK which mention the potential loss of the State, forcing the Ministry of Finance to issue PMK number 130 / PMK.010 / 2012 concerning Registration of Fiduciary Guarantees for finance companies that conduct consumer financing for motorized vehicles with the imposition of Fiduciary Assurance that provides that one month must register.

Then in order to improve service, starting on March 5, 2012, the Directorate General of Public Law Administration of the Ministry of Law and Human Rights (Kemenkumham) has launched an online fiduciary system. Online fiduciary is a breakthrough in the A Ministry of Law and Human Public Administration in providing services to the public. Through this new method by using Notary services, fiduciary legal services are expected to be faster, more accurate and free of extortion. other than that it encourages economic growth considering that services increase state revenues from the Non-Tax State Revenue (PNBP) sector.

However, finance companies still violate the Fiduciary Guarantee Law, among them they conduct fiduciary registration after default debtors or even creditors do not register fiduciary collateral objects at the fiduciary 
registration office on the grounds for efficiency in facing competition from other financing institutions. In this case the creditor is ready to bear the risk if there is a bad credit.

In article 11 paragraph 1 the Fiduciary Guarantee Act states that

"Items loaded with fiduciary guarantees for wajiub are registered," however, there are no restrictions on registration time. This is the basis of why many finance companies do not register their fiduciary guarantees.

Fiduciary collateral is not registered is a violation that is often carried out by creditors, even though creditors are aware of the rules regarding the obligation to register fiduciary guarantees in Article 11 paragraph (1) of the Fiduciary Guarantee Act. The violations committed by creditors in the credit agreement using fiduciary collateral are: the creditor does not register the fiduciary guarantee at the Registration Office of the Fiduciary Guarantee and the creditor registers a fiduciary guarantee after the debtor is in default.

\section{Reconstruction of Security Law on Financing Agreements in the Context of Justice-Based Fiduciary Registration Arrangement of Registration of Fiduciary Assurance as a Credit Guarantee Based on Justice . \\ Registration of a Fiduciary Guarantee is a very important thing to do in terms of obtaining a Fiduciary Guarantee Certificate. Therefore, the regulations governing the registration of fiduciary guarantees should be regulated in detail, firmly and clearly.}

In an era of democracy, the issue of legal certainty is one of the basic values (core values) in the framework of the rule of law, which include the principle that countries should take the lead observance of the law, the judicial authorities are independent (independence of the judiciary), is the entrance to obtaining justice (access to justice) must be completely open, especially for those who are victims of " maladministration" the law must be enforced fairly and equitably (just equal) accompanied by their legal certainty (legal certainty) .

Examining the renewal of the national legal system there are major problems in the national legal system, namely Ius Constitutum (Law Enforcement problem) and Ius Constituendum (Law Reform or Law Development problem . Likewise with fiduciary guarantees, as one of the national laws in practice raises various legal problems including no legal certainty and legal protection. The inconsistency of the substance of a fiduciary guarantee institution, the structure of a fiduciary institution that does not favor SMEs (Small and Medium Enterprises), the unfairness of judges in deciding cases of fiduciary guarantees causes this law to be ineffective.

From the theoretical / conceptual point of view, the Renewal of the National Fiduciary Guarantee Legal System is a series of national legal systems sub-system fiduciary guarantees into the legal substance of fiduciary guarantees, fiduciary guarantee legal structures and fiduciary guarantee legal culture. The national legal system that will be built requires a foundation of values / ideas as guidelines that are in accordance with the life view and ideology of the Indonesian nation so that legal knowledge can apply nationally.

Law and enforcement experience a close and intensive exchange with the political and economic environment. What happens in the legal field is a function of the processes that occur in both fields. There is a thought that law in Indonesia can always be returned to the relationship of political power and community development. Ironically, this situation in the development of legal science in Indonesia is not budding and is dominated by the positivist paradigm. This paradigm is very dominating and even tradition in legal thoughts in Indonesia.

In this study, we will discuss how to reconstruct a fiduciary law system that focuses on the context of fiduciary registration in the context of reforming national law in a better direction, but before the discussion to the above, it is better to discuss first how the legal fiduciary guarantee according to Law Law No. 42 of 1999 concerning fiduciary guarantees.

Legal norms contained in Law No. 42 of 1999, must be a unit consisting of elements in a subsystem that interact with one another harmoniously to achieve what is the purpose of the law. The fiduciary guarantee unit as a material guarantee legal subsystem must be applied to juridical elements such as fiduciary legal regulations, legal principles and legal understandings. Norms are defined as; First, regulations and provisions that bind citizens / communities. ; second, rules, measures or rules that are used as benchmarks for evaluating or comparing things. Hans Kelsen 
describes the distinctive legal meaning of an action originating from a norm whose contents refer to that action, so that it can be interpreted according to the norm. Norms function as a scheme of interpretation, therefore Kelsen interprets the norm as something that should be and should happen.

Law as a norm system, Hans Kelsen argues, that a norm is made according to higher norms, and even higher norms are made according to higher norms as well, and so on until we stop at the highest norm which is not made by the norm anymore but rather its prior existence by the Community or the People. The highest norms are Grundnorm or Basic Norm (Basic Norms), and Grundnorm basically does not change. Through this Grundnorm all legal regulations are arranged in a single hierarchical unit and thus it is also a system. Grundnorm is a source of value for a legal system, so that it can be said that it is "gasoline" that drives the entire legal system. All products of the Act must be sourced from Pancasila as Grundnorm all legal regulations.

The National Legal System must be sourced from the philosophical values / philosophical ideas of the Pancasila law as national law, namely the pillars of Godhead (religious moral) ; legal science is worth / pillar / humanitarian oriented (humanistic); Law is valued / pillared / Community oriented (Nationalistic; Democratic; Social justice).

\section{Reconstruction of Fiduciary Laws in Context of Registration Fiduciary Based on Justice.}

Reconstruction means "Reorganization" in terms of rearranging the building of the Indonesian legal system, so the term restructuring is very close to the meaning of "Reconstruction", namely "Rebuilding" the National legal system. So the two terms are very closely related to Law Reform and Law Development issues, especially with regard to the " Legal Development Discussion System" . In accordance with the dynamics of the national and international economy followed by fast-changing and increasingly complex cultural changes, the Law No. 42 of 1999 concerning Fiduciary Guarantees needs to be rearranged by carrying out reforms at the idealistic level of law so as to be able to respond to realistic laws .

Renewal of the legal system is seen as an integral juridical, constituting a unity of various sub-systems (components) consisting of Components of Legal Substance (Legal Substance), Legal Structure (Legal Structure) and Culture of Law (Legal Culture). Of the three components of the legal system above must be sourced and based on values / ideas that are based on and based on Pancasila as a national legal science oriented to the three pillars / balance of values of Pancasila, Namely: Legal value / pillar / oriented - Godhead ( Religious moral) ; Law is valued / pillared / oriented - Humanity (Humanistic) ; Law is valued / pillared / oriented Community (Nationalistic; Democratic; Social Justice;) .

Based on the opinions above, the framework of the legislators, in this case the Fiduciary Guarantee Law should be oriented to divinity (religious morality), Humanity (Humanistic), and Social (Social Justice), so that the product of the law that it produces it does not cause problems in its implementation in the field (practice) so that the sense of justice, humanity and divinity is truly felt by the community.

Legal culture functions as a bridge that connects legal regulations with the behavior of all members of the community. This legal culture component should be distinguished between the internal legal culture, namely the legal culture of lawyers and judges and external legal culture, namely the legal culture of the wider community.

Legal culture Judges in the legal system of judicial power occupy a central position in upholding the law, in realizing the ideas contained in the law as a product of the political system. The independence of the judiciary is free to hold a court to uphold the law and justice as what has been mandated in article 24 paragraph (1) of the 1945 Constitution. The birth of Law No. 4 of 2004 concerning Judicial Power is expected to be a juridical basis for realizing an independent judicial power and can provide legal certainty and justice and ensure law enforcement (Law Enforcement) is well realized as aspired in the Indonesian constitution.

Justice is the main target of the law, then Reconstruction / Legal Reform must be directed among others to achieve justice both as individuals, as well as justice for the Community or social justice. Not only formal justice, but also substantial justice and even social justice. The role of judges is important in law enforcement efforts in this country, to pay attention to what is called the living law as one of the social facts that needs to be considered in deciding cases that fulfill the sense of justice of society. The living law can be said as a social pressure that can be considered by the judge in deciding the case. 
In connection with the matters mentioned above, it can be interpreted that a legal reconstruction / renewal must be made immediately because the compliance and law enforcement must be upheld especially in regard to Law No. 42 of 1999 concerning Fiduciary Assurance, precisely in the context of fiduciary registration, this is closely related to compliance and law enforcement.

\section{Conclusion:-}

Based on the results of the research and discussion described above, the researcher gives the following conclusions:

1. The application of Fiduciary Guarantee Law No. 42 of 1999 has not fulfilled legal certainty and Norms inconsistency still occurs, so that its implementation still raises legal problems, this occurs because of the legal nature of the fiduciary Guaranty Law by looking at coherence, correspondence and function in the implementation of the provision of bank loans with fiduciary guarantees, it has not yet provided legal certainty, value of benefits and justice for the parties in its implementation. So that it has not been able to achieve the proper level of legal compliance in accordance with what is expected by the Law.

2. Law Enforcement of Laws for Fiduciary Assurance especially regarding Fiduciary Guarantees that are not or too late to be registered are mainly related to non-compliance with the obligation to carry out fiduciary registration, have not been carried out properly as ordered by the Fiduciary Guaranty Law, this is due to lack of strict sanctions is in the Fiduciary Guarantee Act for finance companies that do not conduct fiduciary registration especially in North Sumatra. Therefore, finance companies assume there is no legal risk for the late conduct of fiduciary registration and do not even carry out fiduciary registration at all, so that law enforcement and compliance has not been fully realized.

3. Reconstruction Law Ideal on sub U ndang Fiduciary Fiduciary especially regarding registration should be carried out, where necessary in this case is the substance of the Law of Fiduciary and it needs to be amended in view of discrepancies in Article -pasal and there should be strict sanctions affirmation in Law and not in the regulation of the Finance Minister, given the existence of the Law in the hierarchy of legislation in Indonesia. So it is hoped that this will not open a gap for finance companies to avoid the strict sanctions contained in the Fiduciary Guarantee Act.

\section{Suggestion}

Based on the results of the research and discussion as well as the conclusions that have been described above, the researcher gives several suggestions which include the following:

1. The fiduciary guarantee law needs to be amended immediately by putting strict sanctions, especially in article 11 concerning the obligation of fiduciary registration for motor vehicle finance companies with fiduciary guarantees, this is very closely related to the legal culture of Indonesian people who are less concerned with legal compliance. So that it is expected that later sanctions for delays and even ignorance in carrying out fiduciary registration as well as criminal sanctions relating to the inclusion of Non-Tax State for payment of fiduciary registration fees, will increase legal compliance to the public, especially finance companies.

2. To realize law enforcement, the first thing to do is to realize legal certainty in the Fiduciary Guarantee Act. As already mentioned and alluded to earlier that it is necessary to immediately affirm sanctions for violations of the obligations of fiduciary registration, both in terms of delays and no fiduciary registration at all. Sebel um registration system on line.

3. A guarantee of a good legal system is the guarantee law governing principles and legal norms that doesnt overlap each other. The laws and regulations relating to fiduciary guarantees must be able to run harmoniously and not contain legal norms that are vague with each other, so that the inconsistency in the principles and legal norms of fiduciary guarantees will make it difficult to enforce the law. 


\section{References:-}

1. Anton M Muliono, Kamus Besar Bahasa Indonesia. Jakarta: Balai Pustaka, 1989.

2. A.A.Andi Prayitno, "Hukum Fidusia Problematika Yuridis Pemberlakuan Undang-undang No 42 Tahun 1999," Untag Surabaya 2009.

3. H. out Barda Nawawie Arief, "Kuliah Pembaharuan Hukum Nasional," UNDIP.

4. B. N. Arif, "RUU KUHP Baru Sebuah Restruturisasi / Rekonstruksi Sistem Hukum Pidana Indonesia," UNDIP, 2009.

5. G. Widjya and A. Yani, Jaminan Fidusia. Jakarta: PT. Raja Grafindo Persada, 2003.

6. H. Kelsen, Teori Hukum Murni, Dasar-dasar Ilmu Hukum Normatif, diterjemahkan oleh Raisul muttaqien. Bandung: Nusa Media, 2006.

7. Isnainul.OK., "Kajian Hukum Eksistensi Jaminan Fidusia Pada Perjanjian Finance Leasing Menurut UndangUndang No.42 Tahun 1999," Fakultas Hukum Universitas Muhammadiyah Sumatera, 2009.

8. "Laporan Penelitian Fidusia , Tim Peneliti Hukum Jaminan Kerjasama Bidang Hukum Belanda dengan Indonesia,." .

9. Lawrence M Friedmani, "The Legal System: A. Social Science Perspective." Russel Sage Foundation, New York, 1986.

10. Lawrence M. Friedman, The Legal System; A Social Scince Prespective. New York: Russel Sage Foundation, 1975.

11. Muladi, Pentingnya Lembaga Jaminan Fidusia Dalam Meningkatkan Pembangunan Ekonomi Nasional, Seminar Nasional "Problematika Dalam Pelaksanaan Jaminan Fidusia Di Indonesia; Upaya Menuju Kepastian Hukum. .

12. M. Fuadi, Jaminan Fidusia. bandung: Citra Aditya, 2003.

13. N. A. Susanto, "Dimensi Aksiologis Dari Putusan Kasus 'ST' Kajian Putusan Peninjauan Kembali Nomor 97 PK/Pid.Sus/2012,”J. Yudisial, vol. Vol. 7, no. No. 3.

14. O. H. Tiong, Fidusia sebagai jaminan unsur-unsur perikatan. Jakarta: Ghalia Indonesia, 1985.

15. Ratnawati W Prasojo, "Pokok-pokok Undang-undang Nomor 42 Tahun 1999, tentang Jaminan Fidusia," majalah hukum Tri Sakti , nomor 33 / tahun XXIV/Oktober 1999, 1999.

16. R. Biersted, The Social Order. 1970.

17. Sidharta, Reformasi Peradilan dan Tanggung Jawab Negara, Bunga Rampai Komisi Yudisial, Putusan Hakim: Antara Keadilan, Kepastian Hukum, dan Kemanfaatan,Komisi Yudisial Republik Indonesia. Jakarta, 2010.

18. S. Soekanto, Faktor-faktor yang mempengaruhi penegakan hukum. UI Press, 1983.

19. S. R. Hartono, Hukum Ekonomi Indonesia. Malang: Banyumedia Indonesia Publishing, 2007.

20. Suteki, "Urgensi Sociological Jurisprudence Dalam Pencarian Keadilan Substansial di era Globalisasi, Orasi ilmiah,” Dies Natalis ke 53 Fakultas Hukum UNDIP.

21. T. Kamelo, Hukum Jaminan Fidusia Suatu Kebutuhan Yang di Dambakan. bandung, 2006.

22. Yusriadi, Tebaran Pemikiran Kritis Hukum dan Masyarakat. malang: Surya Penan Gemilang2009, 2009.

23. "Undang-undang Jaminan Fidusia No 42," 1999.

24. "Peraturan Pemerintah Nomor 86," 2000.

25. Kementerian Perindustrian Republik Indonesia, Pertumbuhan Industri Otomotif Diprediksi melejit. .

26. B. Susanto, "Sepeda motor :peran dan tantangan." [Online]. Available: http//www.aisi.or.id /fileadmin/userupload/download/01.bambang Susanto .pdf , diakses tanggal 26 jan 2018\%0A.

27. S. renate Wiranjaya, Persaingan Ketat Dua Raja, Pembiayaan.

28. O. Budi, Ada Potensi Kerugian Negara yang dilakukan Perusahaan Pembiayaan , $\mathrm{http} / \mathrm{www}$. ipotnews.com/m.article/php?OJK ada potensi kerugian negara yang dilakukan perusahaan pembiayaan. 